\title{
STUDY ON SEA LEVEL RISE \\ IN THE WESTERN INDONESIA *)
}

\author{
by \\ Hadikusumah $* *$ )
}

\begin{abstract}
Study on mean sea level (MSL) rise has been done on tide data at some locations in the Western Indonesia. To account the effect of climate change, air temperature analyses from some weather stations are also performed.

The results showed that air temperature has changed between 0.0 to $0.44^{\circ} \mathrm{C}$ per ten years. The sea level analysis showed that mean sea level at Western Indonesia rise between 3.10 to $9.27 \mathrm{~mm}$ per year. Based on the results, the prediction on mean sea level change in the years of 2000, 2030, 2050 and 2100 for Cirebon location are $17 \mathrm{~cm}, 39 \mathrm{~cm}, 55 \mathrm{~cm}$, and $92 \mathrm{~cm}$, respectively.
\end{abstract}

\section{INTRODUCTION}

Greenhouse Effect (GHSE) is caused by the increase of 55\% carbondioxide (CO Remissions; 15\% methane $\left(\mathrm{CH}_{4}\right) ; 24 \%$ chlorofluorocarbons (mainly CFC -11 and CFC - 12 ); and $6 \%$ nitrousoxide $\left\{\mathrm{N}_{2} \mathrm{O}\right.$ ) in the atmosphere (Volker et. al, 1991). The 353 ppmv atmospheric CO., concentration in 1990 is about $25 \%$ greater than the pre-industrial period (1750-1800) concentration (c.a. 280 ppmv.). Carbondioxide in the atmosphere is currently rising at about 1.8 ppmv (0.5\%) per year due to anthropogenic emissions (Anonymous 1992). The increase of GHS gases as mention above will effect run only the earth temperature but also the troposphere temperature. The GHSE is very important to the GCC (Global Climate Changes) because one third of the solar energy entering the atmosphere is reflected back into the space. The two-thirds of that energy absorbed by the earth and re-emitted as infrared radiation. The main factor causing the rise of mean sea level is thermal expansion of surface sea water. Galerkin (Lisitzin 1974) stated that the variations of MSL depend on the changes of density, river discharge, rainfel, evaporation, water transport and air pressure. Other causes are the global ocean and atmospheric behavior as described by Dietrich, 1963 (Lisitzin 1974).

*) Paper Submitted to Fourth International Symposium on Equatorial Atmosphere Observations Over Indonesia, 10-11 November 1992.

**) Research and Development Centre for Oceanology - LIPI. 
Indonesia is the world's largest archipelago consisting of more than 17.000 islands with a total land area of almost 195 million hectares. There are five large islands in Indonesia, i.e., Kalimantan, Sumatera, Irian Jaya, Sulawesi and Java. Indonesia has the long coastline of approximately $81.000 \mathrm{~km}$. Most of Indonesia big cities are located in this area. So, the impact of mean sea level rise (MSLR) to Indonesia can be disastrous. Three major physical impacts on the coastline are inundation of coastal and low lying areas, saltwater intrusion into coastal freshwater aquifers and shallow groundwater, and the change of tidal area in rivers and bays.

Thus, it is important to study how far the mean sea level has been changed and what will be happened in the future. These study is one of the research programme done by Research and Development Centre for Oceanology Lembaga Ilmu Pengetahuan Indonesia (RDCO-LIPI) in cooperation with Ministry of State for Population and Environment (KLH) and Bandung Institute of Technology (ITB). The study was done using tidal data from tide gauge recorded by Directorate General of Sea Communication (PERLA). Meteorological data is from weather stations of the Meteorological and Geophysical Agency (BMG).

\section{MATERIAL AND METHODS}

Sea level change is a natural phenomenon which is occurred periodically or instantaneously. Periodic variations can be occurred either hourly, daily, weekly, monthly, yearly or even more than yearly. The variation of sea level is caused by astronomical and non- astronomical force. Astronomical force is gravitational force by space matters such as moon and sun. These forces caused tides in the earth. Instantaneous changes of sea level variation was caused by meteorological force (such as wind force, atmospheric pressure, air temperature, rainfall, geological force such as coriollis force, vertical earth motion, descent of land surface) and oceanographical force (such as temperature, salinity, density, current and waves).

In studying the rise of mean sea level we employed the method proposed by Rossiter, 1967 (Lisitzin, 1974). This paper presents the results of tidal data analysis in Belawan, Jakarta, Semarang, Surabaya, Panjang, Kuala Tanjung, Cirebon and Tegal (Figure 1). The rise of mean temperature is computed by linear regression method.

\section{RESULTS AND DISCUSSION}

\section{a. Air temperature changes}

The air temperature in Medan from 1971 to 1990 has mean value of $26.42^{\circ} \mathrm{C}$ 
and standard deviation of $0.57^{\circ} \mathrm{C}$. The linear regression analysis on the Medan data showed the air temperature rises $0.034^{\circ} \mathrm{C}$ per year or $0.34^{\circ} \mathrm{C}$ per ten years (Figure 2.a). The values for other locations arc shown in Table I and Fig 2 .

From the mean value of air temperature we recognize three thermal regions. Firstly, the high temperature $\left\{>27^{\circ} \mathrm{C}\right.$ ) region such as Jakarta and Semarang which are big cities Secondly, the moderate temperature $\left(>26-27^{\circ} \mathrm{C}\right)$ region such as Medan, Belawan, Pekanbaru, Jambi and Tegal. Thirdly, the low temperature $\left(>25-26^{\circ} \mathrm{C}\right)$ region such as Kali Jati, which is located on the mountain range area.

Air temperature changes at some stations fluctuated between $0.02^{\circ} \mathrm{C}$ and $0.4^{\circ} \mathrm{C}$ per ten years, this situation corresponds to moderate and low limit scenario prediction which is $0.06^{\circ} \mathrm{C}$ to $0.3^{\circ} \mathrm{C}$ per ten years in Villach and Bellagio Workshops in 1987. The results of temperature analysis in Belawan, Jakarta, Semarang, Surabaya and Ambon (Tim Peneliti ITB 1990) showed the fluctuations of air temperature between $0.0^{\circ} \mathrm{C}$ to $0.89^{\circ} \mathrm{C}$.

\section{b. Sea level changes}

The mean value of yearly mean sea level (MSL) over 14 years (1977 to 1990) at Cirebon tide station, for example, is $59.48 \mathrm{~cm} 4.6 \mathrm{~cm}$, with the minimum and maximum value of $53.09 \mathrm{~cm}$ and $68.28 \mathrm{~cm}$, respectively. The variability explained by the fitted regression model was $84 \%$, and statistically significant. This result is quite good to be used as prediction model. Analysis of secular variation has a positive coefficient which indicates linear trend. The mean sea level at Cirebon station showed a rise of $7 \mathrm{~mm}$ per year. The plot of yearly mean sea level observation, secular variation and other contributing components are presented on Figure 3. The prediction of mean sea level change for years 2000, 2030, 2050 and 2100 are $17 \mathrm{~cm}, 39 \mathrm{~cm}, 55 \mathrm{~cm}$, and $92 \mathrm{~cm}$, respectively.

The mean sea level rise at Cirebon station is higher than those at Panjang, Jakarta, Surabaya, Kuala Tanjung and Tegal, but it is smaller than at Belawan and Semarang (Tim Peneliti ITB 1990). Sec Table II for other comparisons. The differences of those results are expected due to the effect of local river, morphological and topographical forms, and others meteorological or oceanographical processes.

Workshop on mean sea level changes held by CSIRO in October 1989 in Melbourne concluded that the rise of global temperature by $3^{\circ} \mathrm{C}$ in year 2030 will cause the rising of mean sea level by $30 \pm 20 \mathrm{~cm}$. The increase in $\mathrm{CO}_{2}$, concentration and other gasses will cause the warmer world's temperatures by 1.5 to $4.5^{\circ} \mathrm{C}$. This increase of air temperature could cause the rise of mean sea level by $20 \mathrm{~cm}$ up to $140 \mathrm{~cm}$. 
Prediction of the mean sea level rise at Cirebon by year 2030 of $39 \mathrm{~cm}$ is the range of the CSIRO prediction. The average of mean sea level rise for all locations Western Indonesia is $6 \mathrm{~mm}$ per year. The average of sea level changes by year 2000, 2030, 2050 and 2100 are $12 \mathrm{~cm}, 28 \mathrm{~cm}, 41 \mathrm{~cm}$, and $72 \mathrm{~cm}$. respectively (Table II).

From our study there is a clear indication for mean sea level rising. It will become a major problem to Indonesia as maritime country in future. The impact of mean sea level rise is not only to physical, feature of the earth but also to social and economical development. Therefore monitoring programme of sea level changes should be done continuously in order to avoid more hazardous disaster in the future.

\section{Acknowledgment}

The author would like to thanks to Head of Directorate General of Sea Communication, Head of Naval HydroOceanography and Head of Geophysical and Meteorology Agency for providing tide and meteorological data.

He would also like to thank to the Head of Research and Development Centre for Oceanology-LIPI and Second Assistant Minister from Ministry of State for Population and Environment in supporting this projects.

\section{REFERENCES}

Anonymous, 1992. The basic study on strategy response against the global warming and adverse effect on climate change final report. JICA-OECC and KLH.

Hadikusumah and B.S. Soedibjo, 1991 Preliminary study on sea level rise at Lampung Bay. Paper presented at International Seminar on Geodynamic Process in the Forearc Silver Plate. 15-17 October 1991, Bandung, Indonesia.

Lisitzin, E. 1974. Sea Level Change. Elseiver Oceanography Series, Vol. 15, 151-1174. 286 pp.

Tim Peneliti ITB, 1990. Analisis Kenaikan Permukaan Air Laut di Perairan Indonesia. Jurusan Geofisika \& Meteorologi, FMIPA-ITB.

Tim Peneliti P3O-LIPI, 1991. Studi Perubahan Kenaikan Permukaan Laut di Pe-labuhan Panjang.

Tim Peneliti P3O-LIPI, 1991. Studi Perubahan Kenaikan Permukaan Air Laut di Tegal, Puslitbang Oseanologi.

Tim Peneliti KLH, 1992. Pengaruh Perubahan Iklim pada Pengembangan Daerah Pantai Menteri Negara Kependudukan dan Lingkungan Hidup.

Volker, A.M, G. Walter and W. Wei-Chyung, 1991. The conflict over global warming. The application of scientific research to policy choices. Global environment change. Butterworth-Heinemann Ltd. 
Table 1. The rise of air temperature at some locations studied by Tim Peneliti ITB (1990), Tim Peneliti P3O-LIPI (1992) and Tim Peneliti KLH (1992).

\begin{tabular}{|r|l|l|c|c|c|}
\hline No. & Location & $\begin{array}{l}\text { Team } \\
\text { Research }\end{array}$ & Year & $\begin{array}{l}\text { T }\left(^{\circ} \mathrm{C}\right) \\
\text { per 10 Years }\end{array}$ & Mean \\
\hline 1. & Semarang & ITB & 1990 & 0.04 & \\
2. & Surabaya & ITB & 1990 & 0.0 & \\
3. & Ambon & ITB & 1990 & 0.23 & \\
4. & Tegal & P3O-LIPI & 1992 & 0.07 & 26.87 \\
5. & Semarang & P3O-LIPI & 1992 & 0.05 & 27.28 \\
6. & Medan & KLH & 1992 & 0.34 & 26.42 \\
7. & Belawan & KLH & 1992 & 0.3 & 26.86 \\
8. & Pakanbarı & KLH & 1992 & -0.02 & 26.26 \\
9. & Jambi & KLH & 1992 & 0.44 & 26.27 \\
10. & Jakarta & KLH & 1992 & 0.14 & 27.14 \\
11. & Kalijati & KLH & 1992 & 0.07 & 25.89 \\
\cline { 4 - 6 } & & & Average & 0.15 & 26.62 \\
\hline
\end{tabular}

ITB = Bandung Institute of Technology.

KLH = Ministry State for Population \& Environment.

P3O-LIPI = Research \& Development Centre for Oceanology-Indonesian Institute of Sciences. 
Table 2. The rise of mean sea level (MSL) at some tide gauge stations studied by Tim Peneliti ITB (1990). Tim Peneliti P3O-LIPI (1991, 1992) and Tim Peneliti KLH (1992).

\begin{tabular}{|c|c|c|c|c|c|c|c|c|}
\hline \multirow[t]{2}{*}{ No } & \multirow[t]{2}{*}{ Station } & \multirow{2}{*}{$\begin{array}{c}\text { Team } \\
\text { Research }\end{array}$} & \multirow[t]{2}{*}{ Year } & \multirow{2}{*}{$\begin{array}{c}\text { MSL }(\mathrm{mm}) \\
\text { per year }\end{array}$} & \multicolumn{4}{|c|}{$\begin{array}{c}\text { MSL }(\mathrm{cm}) \\
\text { Changes on years }\end{array}$} \\
\hline & & & & & 2000 & 2030 & 2050 & 2100 \\
\hline 1. & Belawan & ITB & 1990 & 7.83 & - & - & 55 & 94 \\
\hline 2. & Jakarta & ITB & 1990 & 4.38 & - & - & 27 & 54 \\
\hline 3. & Semarang & ITB & 1990 & 9.27 & - & - & 56 & 102 \\
\hline 4. & Surabaya & ITB & 1990 & 5.47 & - & - & 33 & 60 \\
\hline 5. & Panjang & P-30-LIPI & 1991 & 4.15 & 11 & 22 & 31 & 52 \\
\hline 6. & Kuala Tanjung & $\mathrm{KLH}$ & 1992 & 3.1 & 7 & 17 & 24 & 42 \\
\hline 7. & Cirebon & KLH & 1992 & 7.0 & 17 & 39 & 55 & 92 \\
\hline \multirow[t]{2}{*}{8.} & Tegal & P30-LIPI & 1992 & 6.4 & 14 & 33 & 46 & 79 \\
\hline & & \multicolumn{2}{|c|}{ Average } & 6 & 12 & 28 & 41 & 72 \\
\hline
\end{tabular}

ITB = Bandung Institute of Technology.

$\mathrm{KLH}=$ Ministry of State for Population and Environment.

P30-LIPI = Research and Development Centre for Oceanology-Indonesian Institute of Sciences. 

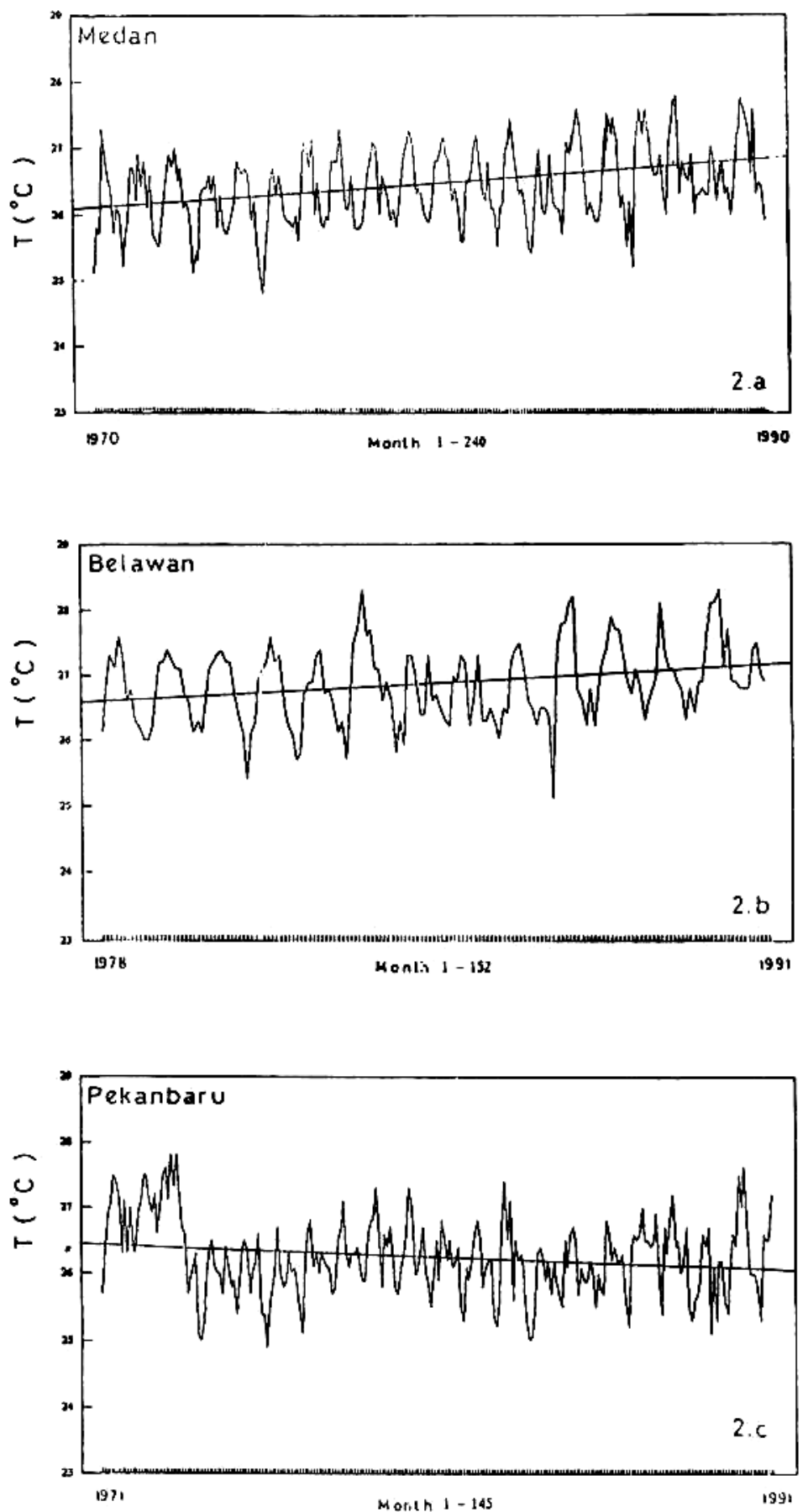

Figure 2. a-c Monthly mean air temperature and the rise tends of air temperature of Medan and Belawan, but for temperature Pekanbaru is going down (drift value on $35^{\text {th }}$ month). 

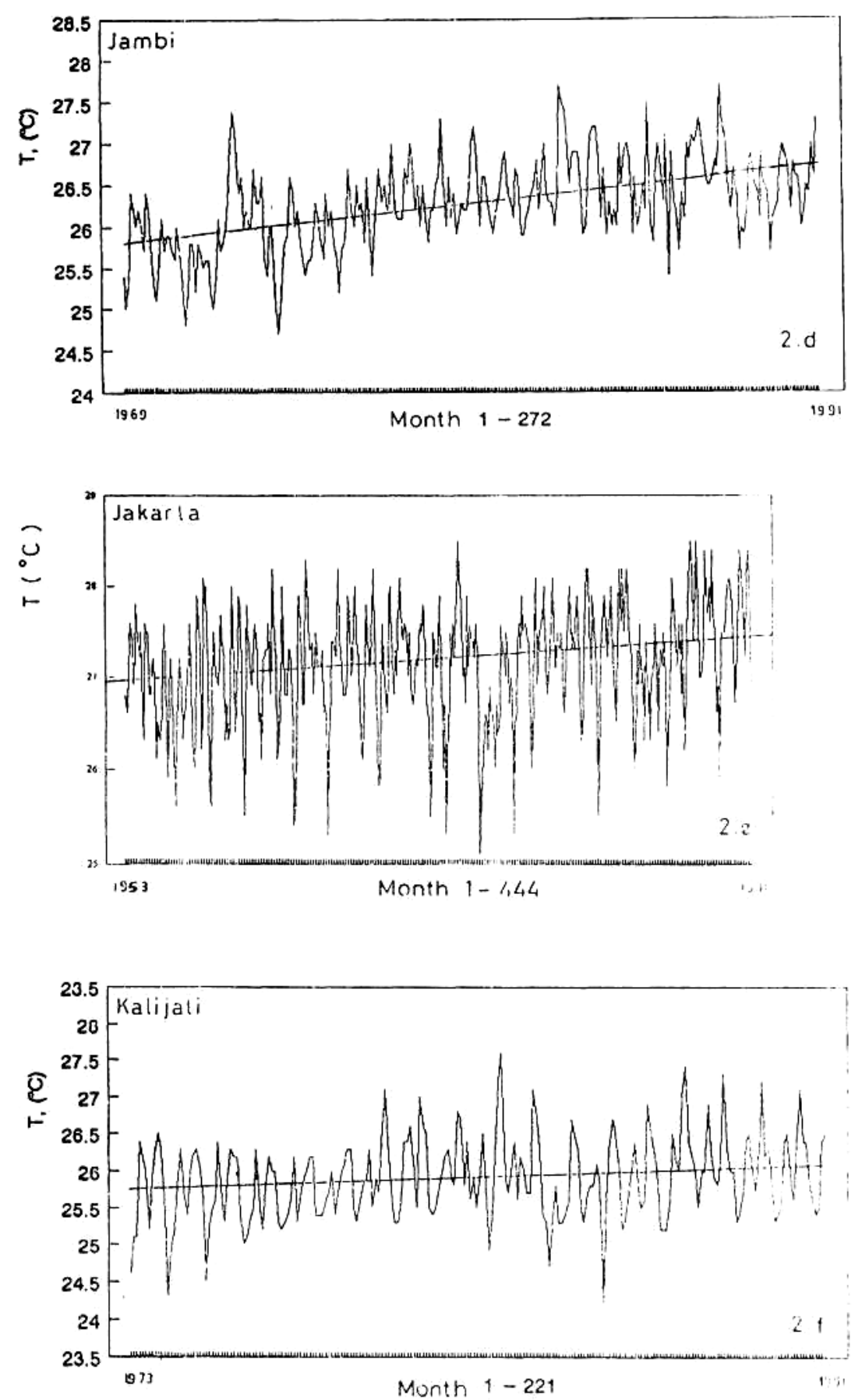

Figure 2. d-f Monthly mean air temperature and the rise tends of air temperature of Jambi, Jakarta and Kalijati. 

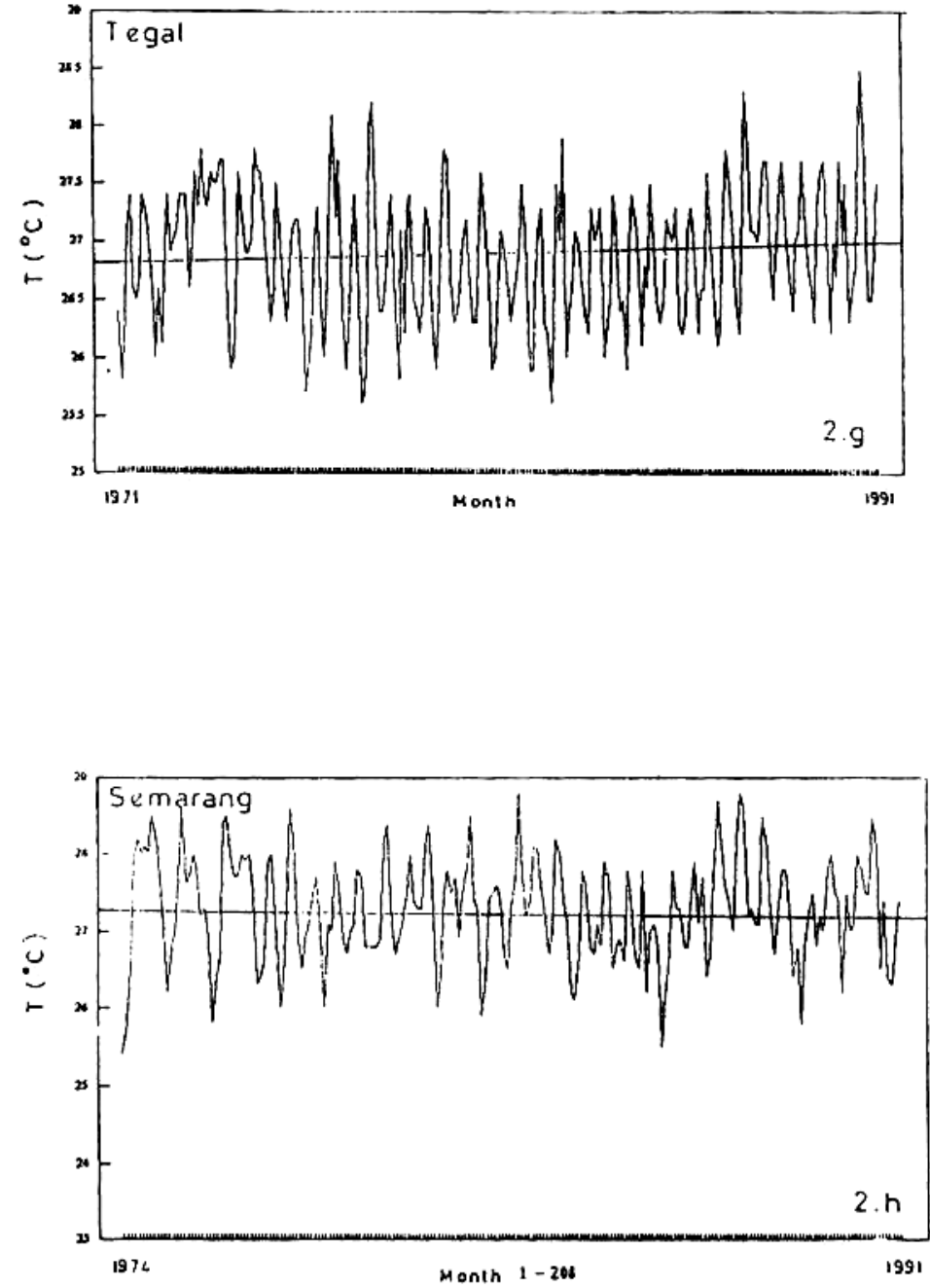

Figure 2. g-h. Monthly mean air temperature and the rise tends of air temperature c Tegal and Semarang. 

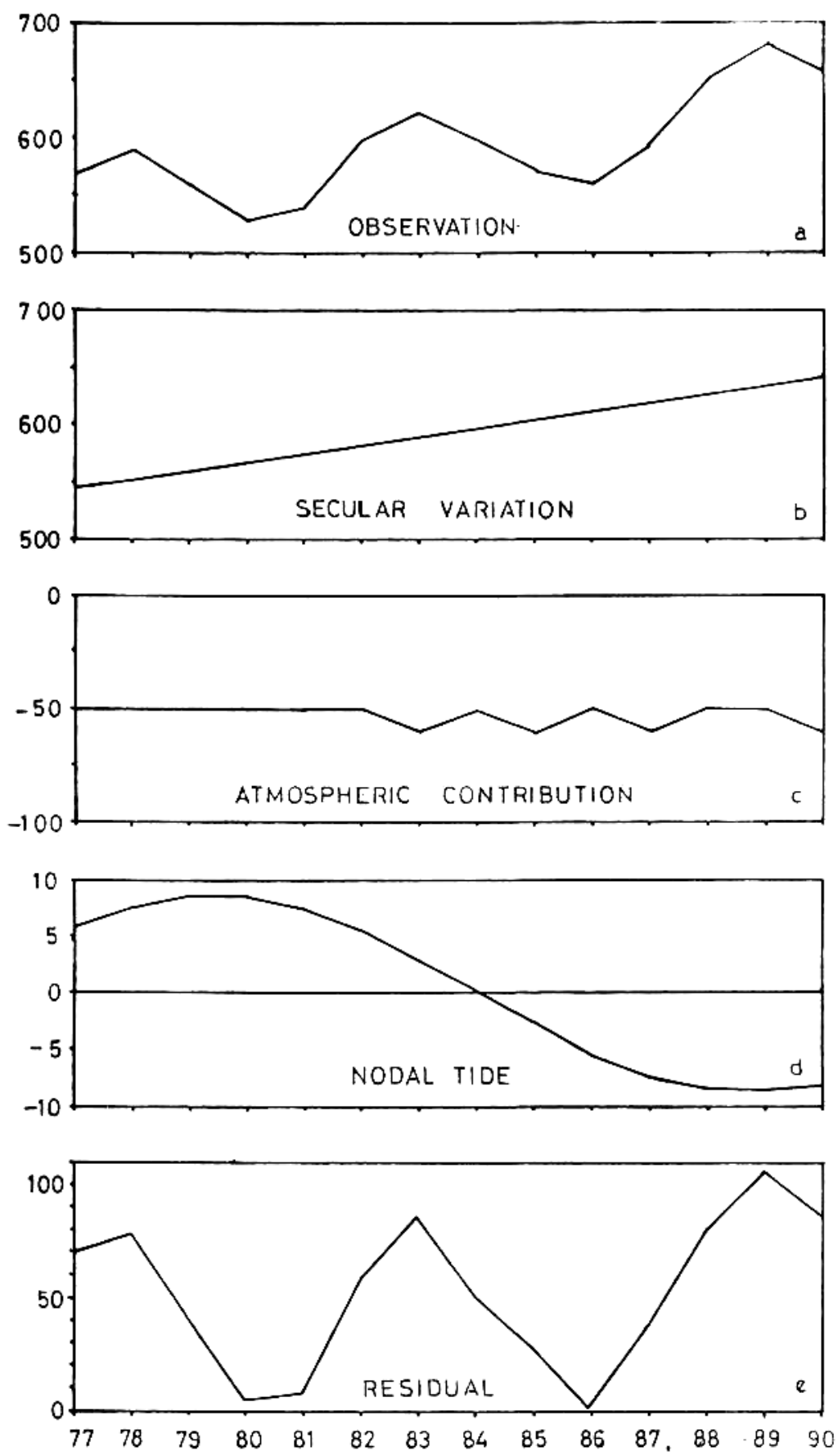

Figure 3. The contribution (in $\mathrm{mm}$ ) of different elements to the mean sea level change at Cirebon tide station 